\title{
火災加熱される木質部材内部の温度・含水率によるヤング係数残存率計算式の導出 DEVELOPMENT OF AN EQUATION CALCULATING YOUNGS MODULUS REMAINING RATIO
WITH TEMPERATURE AND MOISTURE CONTENT WITHIN WOODEN MEMBERS EXPOSED
TO FIRE HEATING
}

\author{
鈴木 達 朗*1, 長谷見 雄二*2, 上川大 輔*3, \\ 安井 昇 ${ }^{* 4}$, 加來千 紘*4, 渡辺秀太 ${ }^{* 5}$ \\ Tatsuro SUZUKI, Yuji HASEMI, Daisuke KAMIKAWA, \\ Noboru YASUI, Chihiro KAKU and Shuta WATANABE
}

\begin{abstract}
Young's Modulus of wood is formulated as functions of temperature and moisture content for the assessment of mechanical performance of wooden members exposed to fire heating. Parameters are determined for 5 tree species common for construction by regression analysis with results of bending tests for temperature between $20^{\circ} \mathrm{C}$ and $250^{\circ} \mathrm{C}$, moisture content between $0 \%$ and $180.5 \%$. Differences of temperature dependence of Young's Modulus between tree species was small at bone-dry state, but large at high moisture content. Young's modulus remaining ratio at high moisture content decrease to 0.57 in Cryptomeria japonica, 0.35 in Zelkova serrata even under $100^{\circ} \mathrm{C}$.
\end{abstract}

Keywords : Wooden Members, Fire Heating, Young's Modulus, Moisture Content, Inner Temperature 木質部材，火㷋加熱，ヤング係数，含水率，内部温度

\section{1 はじめに}

近年、大規模・中高層建築物を木造で可能とする法的整備や技術 開発が進められており、木質部材の負担する荷重の増大やスパンの 長大化が予想される。火災中や火災後の木質部材の信頼性を高める ため、及び適切な大きさで部材の断面を設計するためには、火災加 熱が木質部材の力学的性能に及ぼす影響を予測評価できるようにす る必要がある。

火災加熱を受ける木質部材の力学的性能は、炭化による断面の減 少、及び残存断面の温度上昇により低下寸ることが知られている 1) 3)。これまでも、部材内部で生じる温度分布から力学的性能の低下 を推定し、載荷加熱試験における部材の崩壊時間の算定やたわみ量 の予測が行われている 4 ),5) なと。しかし、木材の力学的性能の含水率 依存性は高温時に上昇するため、温度だけでなく含水率の影響につ いても考慮する必要がある。例えば、スギ、カラマツ等の構造部材 に一般的に用いられる針葉樹についても、常温時と比べた高温時の ヤング係数の低下率は、全乾状態・ $200^{\circ} \mathrm{C}$ の時よりも飽水状態・ $95^{\circ} \mathrm{C}$ の時の方が大きいことが報告されている ${ }^{3), 6) 。 ~}$

さらに、加熱を受ける木質部材内部では圧力差が生じ、水蒸気が
移動、低温部で凝集することにより含水率が上昇する現象が理論的 に考えられ、実際に加熱実験においても部材内部の含水率の上昇が 計測されている 7) 9)。比較的低温となる $100^{\circ} \mathrm{C}$ 以下の領域では火災 中及び火災後の荷重支持能力が期待されるが、含水率が上昇すると 力学的性能の顕著な低下を招きか㸚ないこととなる。このように、 木質部材の火災時の力学的性能を予測評価するには、断面内部の温 度分布のみならず、含水率分布を明らかにし、温度、含水率の力学 的性能一の影響を考慮する必要がある。

しかし、灭災加熱時に変化する温度・含水率と力学的性能の関係 は、温度、含水率、及び双方の相乗効果による影響を考慮する必要 があり、これまで定量的に表現されていない。Euro Codeにおいて も、木材の高温時の力学的性能は温度上昇のみにより低下寸るもの とされ、温度と含水率の双方が変化する場合の力学的性能の低下は 考慮されていない10)。

そこで本研究では、力学的性能としてヤング係数を対象とし、火 災加熱時の部材内部の温度と含水率がヤング係数に与える影響を定 量的に表現することを試みる。具体的には、温度と含水率を引数と してヤング係数を算出する最適な式を導出する。ヤング係数を算出
*1 大成建設技術センター 修士 (工学) (当時、早稲田大学)

*2 早稲田大学理工学術院 教授. 工博

*3 国立研究開発法人森林研究整備機構 博士 (工学)

*4 早稲田大学理工学術院総合研究所 招聘研究員・博士 (工学)

*5 住友林業 修士 (工学) (当時、早稲田大学)
Technology Center, Taisei Corp., M.Eng. (Formerly Waseda Univ.)

Prof., Faculty of Science and Engineering, Waseda Univ., Dr.Eng.

Forestry Research and Management Organization, Ph.D.

Adjunct Researcher, WISE, Waseda Univ., Ph.D.

Sumitomo Forestry Corporation, M.Eng. (Formerly Waseda Univ.) 
する式は回帰分析により求め、筆者らが行った温度及び含水率をパ ラメータとした小試験体の曲げ試験の結果 2 (2),3,6),11)のうち 5 樹種を 回帰分析の対象とする。最後に、回帰分析の結果から樹種によるヤ ング係数の温度・含水率依存性の差異を考察し、本研究の回帰分析 の対象外となる樹種のヤング係数予測への適用可能性を検討する。

\section{2 検討方針}

\section{1 対象とする力学的性能}

火災加熱時の力学的性能の変化を予測するためには、加熱前と比 較して、加熱中及び加熱後の高温時にどの程度力学的性能が残存し ているか把握することが望ましい。ヤング係数については、加熱前 に非破壊で計測し、加熱後の高温時に計測した值と比較することで 高温時の残存率を算出することが可能である。曲げ強度や圧縮強度 は非破壊では算出できないため、ヤング係数の残存率を定式化する ことを目標とする。

加熱後のヤング係数の残存率は、加熱前後の温度及び含水率の変 化を考慮し、式（1)でヤング係数残存率 $R_{E}$ として定義する。

$R_{E}=\frac{E(T, M)}{E\left(T_{0}, M_{0}\right)}$

$R_{E}$ : Young's Modulus Remaining Ratio

$E(T, M)$ : Young's Modulus at Temperature $T$ and Moisture Content $M$

$\left[\mathrm{N} / \mathrm{mm}^{2}\right]$

$E\left(T_{0}, M_{o}\right)$ : Young's Modulus at Initial Temperature $T_{o}$ and Initial Moisture Content $M_{0}$

$\left[\mathrm{N} / \mathrm{mm}^{2}\right]$

\section{2 基本式}

本研究では、温度及び含水率を引数としてヤング係数残存率を計 算可能にするため、以下の基本式(2)を元に回帰式を作成し、回帰分 析を行う。ヤング係数は、高温時は常温時よりも含水率の力学的性 能への影響が増大寸る ${ }^{3,6), 11}$ ことから、温度・含水率がそれぞれ独立 して変化した場合以外に、温度と含水率の双方が同時に変化した場 合のヤング係数の低下を考慮する必要がある。よって、温度、含水 率、及びその双方の変化によるヤング係数の低下率を、それぞれ $D_{T}(T) 、 D_{M}(M) 、 D_{T M}(T, M)$ として表した。 $D_{T}(T) 、 D_{M}(M) 、 D_{T M}(T, M)$ は加熱前後の温度や含水率の変化に依存する值であるが、各項の詳 細については回帰分析を行う 4 章にて定義する。
$R_{E}=1-D_{T}(T)-D_{M}(M)-D_{T M}(T, M)$

where $D_{T}(T)$ and $D_{M}(M)$ represent decreasing ratio of Young's Modulus of wood by the single increase of temperature and moisture content respectively, and $D_{T M}(T, M)$ represents additional effect due to the simultaneous change of temperature and moisture content .

\section{3 回帰分析の対象と温度漸増曲げ試験}

本研究では、基本式(2)を回帰式として、温度及び含水率をパラメ 一タとする既報 2),3),6),11)の曲げ試駼結果を対象に回帰分析を行う。既 報 2),3,6),11)では、断面 $20 \mathrm{~mm}$ 角 $\times$ 長さ $320 \mathrm{~mm}$ の無欠点小試験体を 用いた曲げ試験を行い、温度及び含水率のヤング係数への影響を調 査している。Table1 に実験条件と条件ごとの試験体本数を示す。

回帰分析の対象と寸る樹種は、常温 $250^{\circ} \mathrm{C}$ 、含水率 $0 \sim 30 \%$ 以上 の Table1 の全条件にて実験の行われているスギ、ヒノキ、カラマ ツ、ベイマツ及びケヤキの 5 樹種を対象とする。

また、本研究では基本式(2)における $D_{T M}(T, M)$ の表現方法を決定 するため、試験体の温度を段階的に徐々に上昇させながらヤング係 数を計測する曲げ試験（以下、温度漸増曲げ試験と称す）を行う。

基本式(2)における $D_{T}(T) 、 D_{M}(M) 、 D_{T M}(T, M)$ につい、それぞ れ回帰式を作成するための基本的な知見を整理すると、 $D_{T}(T)$ につ いては、温度上昇に伴いヤング係数が徐々に低下し、熱分解開始温 度を超えるとさらに低下が顕著になり 2),3)、約 $260^{\circ} \mathrm{C}$ で炭化に至る ことが明らかとなっている ${ }^{1}$ 。 $D_{M}(M)$ につては、含水率上昇に伴 いヤング係数は低下し、約 $30 \%$ の繊維飽和点以上ではヤング係数は

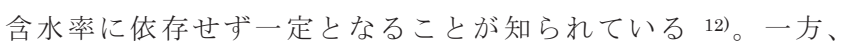
$D_{T M}(T, M)$ については、高温時にはヤング係数の含水率依存性が増 大寸ることがわかっており、Table 1 においても常温、50,80,95 C 限定された温度条件の下ではヤング係数の含水率依存性が調べられ ている。ただし、高温時の含水率依存性の増大は、高温・飽水状態 でリグニンやへミセルロースが熱軟化することに起因する 13) と考 えられるため、温度上昇時にそれらの熱軟化が始まるとヤング係数 の低下が顕著になると考えられる。しかし、飽水状態で温度上昇時 にヤング係数が低下寸る過程については知見が乏しいため、温度漸 増曲げ試験を行い調査するものとした。

Table1 The number of bending test specimens in Ref. ${ }^{2), 3), 6), 11)}$ applied for regression analysis in this study

\begin{tabular}{|c|c|c|c|c|c|c|c|c|c|c|c|c|c|c|c|c|c|c|c|c|c|c|c|}
\hline \multirow{2}{*}{\multicolumn{3}{|c|}{ Tree Species }} & \multirow{4}{*}{$\begin{array}{c}\text { Average } \\
\text { of } \\
\text { Densities } \\
{\left[\mathrm{g} / \mathrm{cm}^{3}\right]}\end{array}$} & \multicolumn{20}{|c|}{ Temperature } \\
\hline & & & & \multicolumn{20}{|c|}{ Moisture Content[\%] } \\
\hline \multirow{2}{*}{$\begin{array}{l}\text { Hard Wood } \\
\text { or } \\
\text { Soft Wood }\end{array}$} & \multirow{2}{*}{$\begin{array}{l}\text { Specific } \\
\text { name }\end{array}$} & \multirow{2}{*}{$\begin{array}{l}\text { Japanese } \\
\text { name }\end{array}$} & & \multicolumn{4}{|c|}{ RT } & \multicolumn{4}{|c|}{$50^{\circ} \mathrm{C}$} & \multicolumn{4}{|c|}{$80^{\circ} \mathrm{C}$} & \multicolumn{4}{|c|}{$95^{\circ} \mathrm{C}$} & \multirow{2}{*}{$\frac{100^{\circ} \mathrm{C}}{0^{* 2}}$} & \multirow{2}{*}{$\frac{150^{\circ} \mathrm{C}}{0^{* 2}}$} & \multirow{2}{*}{$\frac{200^{\circ} \mathrm{C}}{0^{* 2}}$} & \multirow{2}{*}{$\frac{250^{\circ} \mathrm{C}}{0^{* 2}}$} \\
\hline & & & & $0-5$ & $5-151$ & $15-30$ & $30-$ & $0-5$ & $5-151$ & $15-30$ & $30-$ & $0-5$ & $5-151$ & $15-30$ & $30-$ & $0-5$ & $5-151$ & $15-30$ & $30-$ & & & & \\
\hline \multirow{6}{*}{ Soft Wood } & Cryptomeria japonica & スギ & 0.362 & $34(14)^{* 1}$ & 16 & 17 & 18 & 15 & 15 & 13 & 17 & 15 & 15 & 14 & 16 & 15 & 17 & 10 & 18 & 20 & 20 & 20 & $20^{* 3}$ \\
\hline & Chamaecyparis obtusa & ヒノキ & 0.427 & 15 & 17 & 12 & 16 & 15 & 17 & 11 & 17 & 15 & 17 & 11 & 17 & 15 & 18 & 11 & 16 & 15 & 15 & 15 & $15^{* 3}$ \\
\hline & Larix leptolepis & カラマツ & 0.516 & $26(12)^{* 1}$ & 33 & 12 & 22 & 12 & 35 & 12 & 21 & 15 & 18 & 13 & 21 & 13 & 21 & 13 & 13 & 15 & 15 & 15 & 14 \\
\hline & Pseudotsuga menziesii & ベイマッ & 0.490 & $30(15)^{* 1}$ & 15 & 20 & 16 & 12 & 19 & 20 & 16 & 15 & 16 & 19 & 16 & 15 & 16 & 19 & 16 & 15 & 15 & 15 & 15 \\
\hline & Picea sitchensis & スプルース & 0.431 & 10 & - & - & - & - & - & - & - & - & - & - & - & 15 & - & - & 15 & - & - & 10 & 15 \\
\hline & Tsuga mertensiana & ベイツガ & 0.482 & 10 & - & - & - & - & - & - & - & - & - & - & - & 15 & - & - & 15 & - & - & 10 & 15 \\
\hline \multirow{3}{*}{ Hard Wood } & Zelkova serrata & ケヤキ & 0.576 & $29(14)^{* 1}$ & 21 & 20 & 19 & 15 & 15 & 24 & 17 & 15 & 13 & 23 & 21 & 15 & 19 & 15 & 21 & 16 & 16 & 16 & 16 \\
\hline & Castanea crenata & クリ & 0.412 & 10 & - & - & - & - & - & - & - & - & - & - & - & 15 & - & - & 15 & - & - & 10 & 15 \\
\hline & Quercus myrsinifolia & シラカシ & 0.717 & 10 & - & - & - & - & - & - & - & - & - & - & - & 15 & - & - & 15 & - & - & 10 & 15 \\
\hline
\end{tabular}

*1 The number of specimens in ( ) have been applied for regression analysis in this study because specimens without moisture content measurement had been excluded.

*2 The tests have conducted at $230^{\circ} \mathrm{C}$ in Cryptomeria japonica and Chamaecyparis obtusa because specimens had ignited at $250^{\circ} \mathrm{C}$.

*3 Specimens had dried in the oven at $60^{\circ} \mathrm{C}$ enough time before bending tests. 
本研究では、3 章にて温度漸増曲げ試験を行い、4 章では回帰式 の決定及び回帰分析を行う。回帰式の決定では $D_{T}(T) 、 D_{M}(M)$ 、 $D_{T M}(T, M)$ 表現方法を決定し、3 章の温度漸増曲げ試験の結果を $D_{T M}(T, M)$ の回帰式の形を決定する際に参照する。

\section{3 温度漸増曲げ試験}

\section{1 実験方法}

実験は、既報 2),3,66,11) と同じ(国研)森林研究・整備機構内の恒温炉 付曲げ試験機(Photo1)を用い、常温時及び高温時のヤング係数を測 定する。試験体及び載荷方法は JIS Z 2101「木材の曲げ試験方法」 に準じ、Fig.1 に示す二方柾の試験体とした。常温時及び高温時のヤ ング係数は、単純梁に中央集中荷重がかかるものとし、以下の式(3) により算出した。載荷は載荷速度 $1.0 \mathrm{~mm} / \mathrm{min}$ 、最大荷重が $0.25 \mathrm{kN}$ となるまで行い、ヤング係数は弾性範囲である $0.1 \sim 0.2 \mathrm{kN}$ の範囲 の割線で計算を行った。

$E=\frac{\Delta P L^{3}}{48 \Delta \delta I}$

$E$ : Young's Modulus

$\left[\mathrm{N} / \mathrm{mm}^{2}\right]$

$\Delta P$ : Differences of load in elastic region

$[\mathrm{N}]$

$L$ : Supporting point span

[mm]

$\Delta \delta$ : Differences of deflection at the mid-span

[mm]

$I$ : Moment of interior area

$\left[\mathrm{mm}^{4}\right]$

実験は、加熱と載荷によるクリープの影響を最小限にするため、 載荷を継続したまま加熱するのではなく、加熱により所定の温度に 達したら載荷・除荷し、再び加熱することを繰り返すこととした。 なお、加熱中の水分蒸発及び試験体内部の含水率分布のばらつき を最小限に寸るため、既報 33 ,6),11) と同様に試験体にアルミホイルを

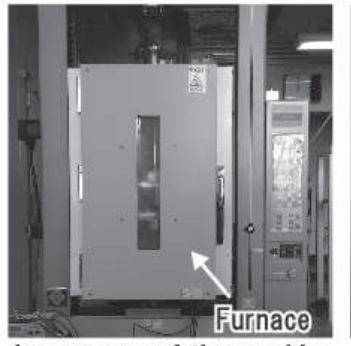

Appearance of the machine

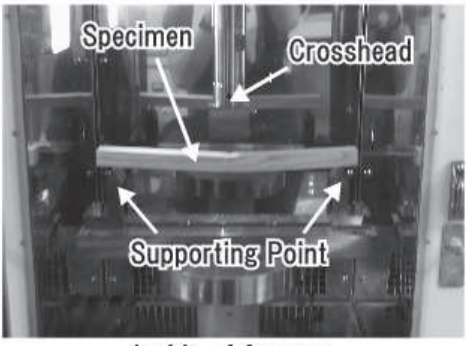

Inside of furnace
Photo1 Bending machine with furnace

320

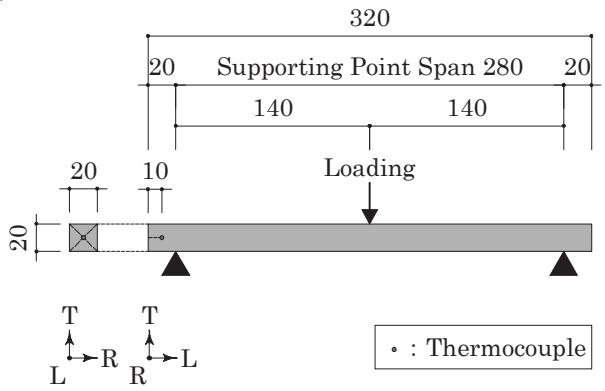

Fig.1 Specimen ( unit : mm )
巻いた状態で加熱、載荷を行った。試験体の加熱による含水率の変 化は、全乾状態の試験体は加熱前後で最大約 $0.5 \%$ とさかった。ま た、繊維飽和点以上の試験体は加熱前後で最大 $3.3 \%$ あるが、繊維 飽和点を十分に超えている範囲での変化のため力学的性能への影響 は小さく、試験体の含水率は加熱中に一定であるものとする。すな わち、温度漸増曲げ試験では式(1)において $M=M_{0}$ とみなす。

以下、実験方法を示す。

(1)試験体の設置

試験体を Photo1 の恒温炉内の載荷装置に設置し、常温時ヤング 係数 $E\left(T_{0}, M_{0}\right)$ を計測する。試験体は試験の直前まで $20^{\circ} \mathrm{C} の$ 室内に 安置していることから、 $T_{0}=20\left[{ }^{\circ} \mathrm{C}\right]$ とした。

(2)試験体の加熱

恒温炉の温度を実験条件の温度より $1 \sim 2^{\circ} \mathrm{C}$ 高く設定し、試験体を 加熱する。

(3)高温時のヤング係数の計測

Fig.2 の位置に設置した試験体の内部温度が実験条件の温度に達 した時点で、高温時のヤング係数 $E(T, M)$ を計測する。

(4)加熱、ヤング係数の計測(2、(3)の手順)を繰り返す。

(5)含水率の算出

$95^{\circ} \mathrm{C}$ でヤング計測した後、試験体を直ちに取り出し質量を計測す る。 $105^{\circ} \mathrm{C}$ の恒温炉で試験体を乾燥し、以下の式(4)により含水率を 算出する。
$M=\frac{W_{w e t}-W_{d r y}}{W_{d r y}} \times 100$

$M$ : Moisture Content

$W_{\text {wet }}$ : Weight (wet)

$W_{d r y}$ : Weight (dry)
(4)

[\%]

[g]

$[\mathrm{g}]$

\section{2 実験条件}

実験条件の一覧と、試験体ごとの常温時のヤング係数、加熱後に 算出した含水率、全乾質量の一覧を Table 2 に示す。実験は、既報 2),3),6),11) にて調查が行われている 9 樹種を対象とした。高温時の力学 的性能に含水率が影響しない場合、及び最も影響する場合を調べる ため、各樹種につき全乾状態、含水率が繊維飽和点以上(以下、飽水 状態と称する)の試験体を 1 体ずつ用いた。試験体は、全乾状態の試 験体は $60^{\circ} \mathrm{C}$ の恒温槽で予め乾燥を、飽水状態の試験体は気乾状態の 試験体に減圧加圧注水を行い用意した。高温時のヤング係数の測定 は、広葉樹の方が比較的低温から軟化しやすいとの知見 13)から、広 葉樹では $40^{\circ} \mathrm{C}$ から $95^{\circ} \mathrm{C}$ 、針葉樹では $50^{\circ} \mathrm{C}$ から $95^{\circ} \mathrm{C}$ 範囲におい て $5{ }^{\circ} \mathrm{C}$ 刻みで計測した。恒温炉の設定温度は、実験条件の温度と比 べ、全乾状態の試験体で $1^{\circ} \mathrm{C}$ 高く、繊維飽和点以上の含水率の試験 体で $2^{\circ} \mathrm{C}$ 高く設定した。

本研究では、各条件 1 体ずつの試験を行っているが、試験体ごと に力学的性能にばらつきが生じるため、樹種ごとにヤング係数残存 率を比較するためには複数体の試験を行い、平均值を算出する必要 がある。例えば、JIS Z 2101「木材の曲げ試験方法」には 12 体以上 の試験を行うことと記載されている。Table2 において、同じ樹種の 常温時のヤング係数は、繊維飽和点以上の含水率の時の方が全乾状 態よりも高くなっている場合があり、ばらつきによるものと考えら 
れる。よって、本研究では含水率の違いによる温度上昇時のヤング 係数残存率の低下傾向やその近似方法について考察を行い、樹種ご とのヤング係数残存率值の差異については詳細な考察は行わないも のとする。

Table 2 Test conditions of bending tests with temperature increasing

\begin{tabular}{|c|c|c|c|c|c|c|}
\hline \multicolumn{3}{|c|}{ Tree Species } & \multirow[b]{2}{*}{ Conditions } & \multirow{2}{*}{$\begin{array}{l}\text { Young's } \\
\text { Modulus } \\
\text { at RT } \\
{\left[\mathrm{N} / \mathrm{mm}^{2}\right]}\end{array}$} & \multirow[b]{2}{*}{$\begin{array}{c}\text { Moisture } \\
\text { Content } \\
{[\%]}\end{array}$} & \multirow{2}{*}{$\begin{array}{c}\text { Bone- } \\
\text { dry } \\
\text { density } \\
{\left[\mathrm{g} / \mathrm{cm}^{3}\right]}\end{array}$} \\
\hline $\begin{array}{l}\text { Hard Wood } \\
\text { or } \\
\text { Soft Wood }\end{array}$ & $\begin{array}{c}\text { in } \\
\text { English }\end{array}$ & $\begin{array}{c}\text { in } \\
\text { Japanese }\end{array}$ & & & & \\
\hline \multirow{12}{*}{ Soft Wood } & \multirow{2}{*}{ Cryptomeria japonica } & \multirow{2}{*}{ スギ } & Bone-dry state & 9328 & 4.1 & 0.380 \\
\hline & & & over FSP* & 11000 & 108.3 & 0.423 \\
\hline & \multirow{2}{*}{ Chamaecyparis obtusa } & \multirow{2}{*}{ ヒノキ } & Bone-dry state & 10530 & 4.8 & 0.405 \\
\hline & & & over FSP* & 8114 & 147.0 & 0.421 \\
\hline & \multirow{2}{*}{ Larix leptolepis } & \multirow[t]{2}{*}{ カラマツ } & Bone-dry state & 9649 & 3.7 & 0.529 \\
\hline & & & over FSP* & 10550 & 70.5 & 0.546 \\
\hline & \multirow[t]{2}{*}{ Pseudotsuga menziesii } & \multirow{2}{*}{ ベイマッ } & Bone-dry state & 13420 & 3.6 & 0.534 \\
\hline & & & over FSP* & 11920 & 57.8 & 0.511 \\
\hline & \multirow[t]{2}{*}{ Picea sitchensis } & \multirow[t]{2}{*}{ スプルース } & Bone-dry state & 11240 & 1.6 & 0.436 \\
\hline & & & over FSP* & 11550 & 48.5 & 0.454 \\
\hline & \multirow[t]{2}{*}{ Tsuga mertensiana } & \multirow{2}{*}{ ベイツガ } & Bone-dry state & 12050 & 0.9 & 0.471 \\
\hline & & & over FSP* & 14340 & 45.8 & 0.526 \\
\hline \multirow{6}{*}{ Hard Wood } & \multirow[t]{2}{*}{ Zelkova serrata } & \multirow[t]{2}{*}{ ケヤキ } & Bone-dry state & 11220 & 3.1 & 0.579 \\
\hline & & & over FSP* & 9440 & 75.5 & 0.557 \\
\hline & \multirow{2}{*}{ Castanea crenata } & \multirow{2}{*}{ クリ } & Bone-dry state & 6852 & 3.1 & 0.440 \\
\hline & & & over FSP* & 7652 & 95.1 & 0.440 \\
\hline & \multirow[t]{2}{*}{ Quercus myrsinifolia } & \multirow[t]{2}{*}{ シラカシ } & Bone-dry state & 9503 & 3.9 & 0.727 \\
\hline & & & over FSP* & 9580 & 66.8 & 0.709 \\
\hline
\end{tabular}

* Fiber Saturation Point

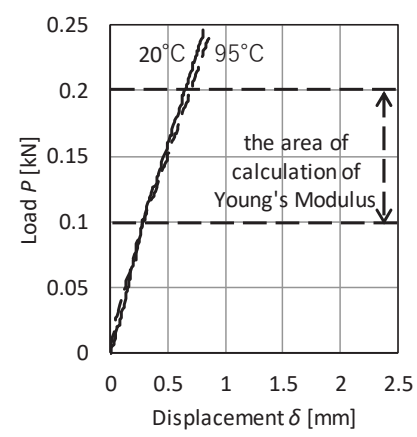

Bone-dry state

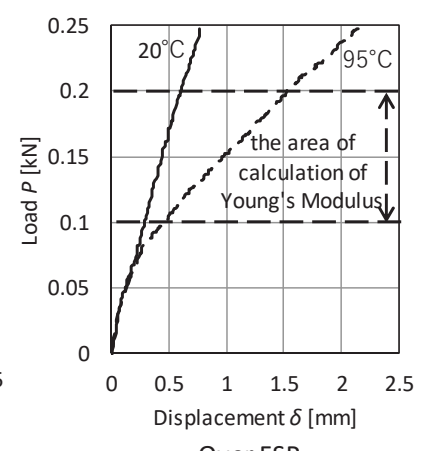

Over FSP
Fig.2 Load-Displacement curve(Cryptomeria japonica, スギ)

\section{3 実験結果}

\subsection{1 試験体の温度履歴}

炉内温度と試験体の内部温度の推移を Fig.3 に示す。代表例とし て、全乾状態の試験体のうち最も密度が低く合計加熱時間が短かっ たスギ、及び繊維飽和点以上の含水率の試験体のうち最も密度が高 く、合計加熱時間が長かったシラカシを示している。Fig.3 中のプロ ットは、試験体の内部温度が実験条件に達した時間を示しており、 各実験条件の温度でヤング係数の測定が終わった後、次の実験条件 の温度へ炉内の昇温を開始した。全乾状態のスギでは 65.5 分、纎維 飽和点以上の含水率のシラカシでは 166 分を加熱に要した。

全乾状態のスギでは、 $50^{\circ} \mathrm{C}$ までに 15 分の加熱、その後の実験実 験条件ごとに $5 \sim 6$ 分の加熱を要した。繊維飽和点以上の含水率の シラカシでは、 $40^{\circ} \mathrm{C}$ までの 33 分の加熱を要し、実験条件ごとでは $45^{\circ} \mathrm{C}$ で 10 分、 $95^{\circ} \mathrm{C}$ で 19 分と、高温時ほど加熱に時間を要した。

\subsection{2 荷重変位関係}

荷重変位関係の代表例として、スギの 20 及び $95^{\circ} \mathrm{C}$ 、全乾状態及 び繊維和飽和点以上の含水率の時の荷重変位関係を Fig.2 に示寸。

全乾状態では、 $20^{\circ} \mathrm{C} 、 95^{\circ} \mathrm{C}$ のい゙れもおおよそ線形に推移してお り、ヤング係数は $95^{\circ} \mathrm{C}$ では $20^{\circ} \mathrm{C}$ と比較して 0.90 倍に低下している。

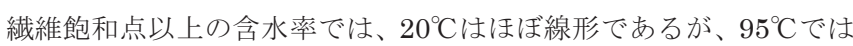
載荷荷重約 $0.1 \mathrm{kN}$ 以上の範囲で荷重変位関係の傾きが緩やかとな っており、ヤング係数は $20^{\circ} \mathrm{C}$ と比較して 0.51 倍に低下している。 本実験におけるヤング係数の計算範囲は $0.1 \sim 0.2 \mathrm{kN}$ であるため、 荷重変位関係の傾きが緩やかとなった後の範囲でヤング係数が計算 されており、算定方法に大きな問題はないと考らえられる。

\subsection{3 温度上昇時のヤング係数残存率の変化}

温度漸増曲げ試験の実験結果を樹種ごとに Fig.4 に示す。いずれ の樹種においても温度上昇に伴いヤング係数残存率が低下し、全乾 状態よりも飽水状態の方がヤング係数残存率は低く推移した。

全乾状態の試験体は、 $95^{\circ} \mathrm{C}$ 時に最小值がシラカシ 0.79 、最大值が ヒノキ 0.95 となった。全乾状態では、含水率による熱軟化の影響は なく、熱分解が起こる温度以下である $\left.{ }^{14}\right)$ た、、温度上昇に伴い線形 にヤング係数残存率が低下寸ると仮定し、Fig. 2 に最低温度 $20^{\circ} \mathrm{C}$ と 最高温度 $95^{\circ} \mathrm{C}$ のング係数残存率を直線で結び示した。 $20^{\circ} \mathrm{C}$ と $95^{\circ} \mathrm{C}$ のング係数残存率を結ぶ直線は、スプルース及びシラカシで 実験值よりも低く推移したものの、おおよそ実験值を表現できてい ると考えられる。

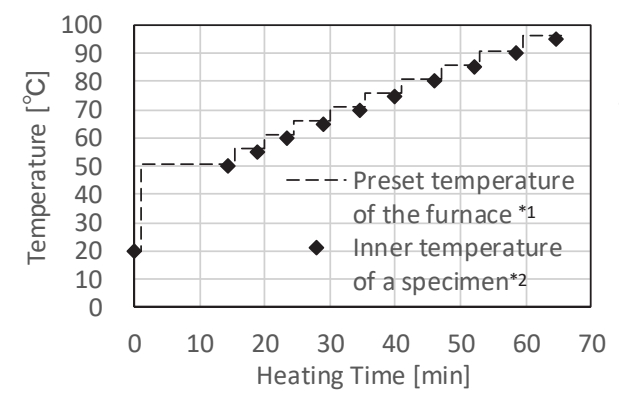

Cryptomeria japonica ( スギ), Bone-dry state

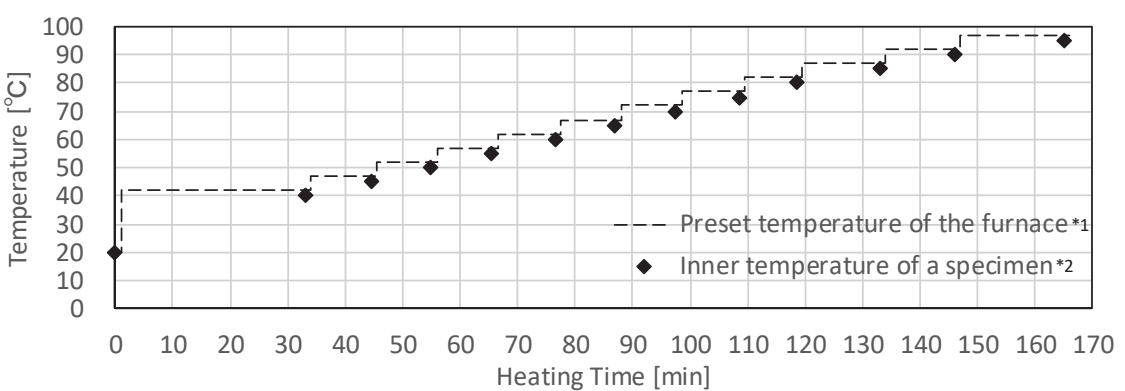

Quercus myrsinaefolia (シラカシ) , over FSP

*1 It took about 1 minutes from preset temperature was increased to temprature of the furnace reached preset temparature.

$*_{2}$ The time when inner temperature of a specimen reached temperature of test conditon was plotted.

Fig.3 Time history of Preset temperature of the furnace and Inner temperature of specimens 


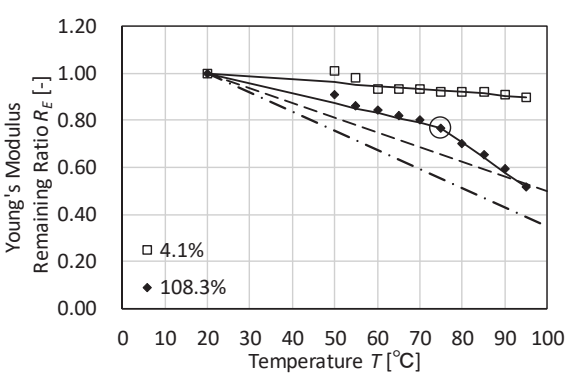

Cryptomeria japonica（スギ）

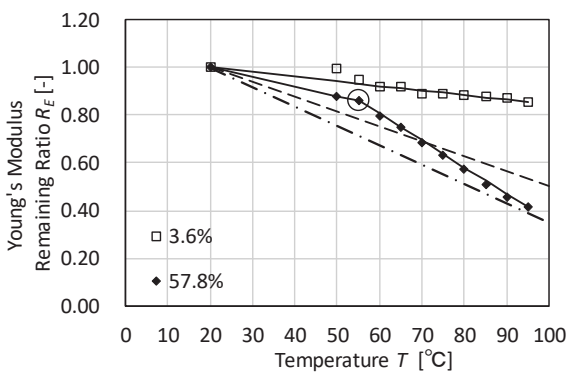

Pseudotsuga menziesii（ベイマッ)

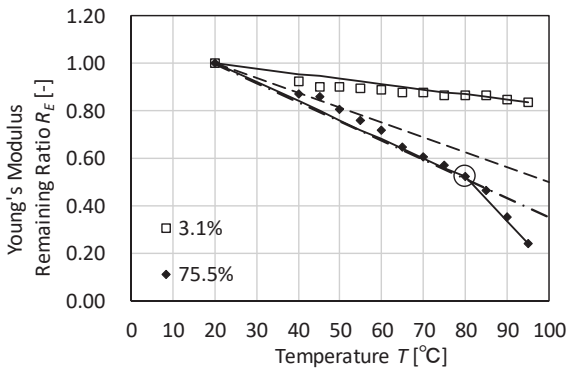

Zelkova serrata（ケヤキ）

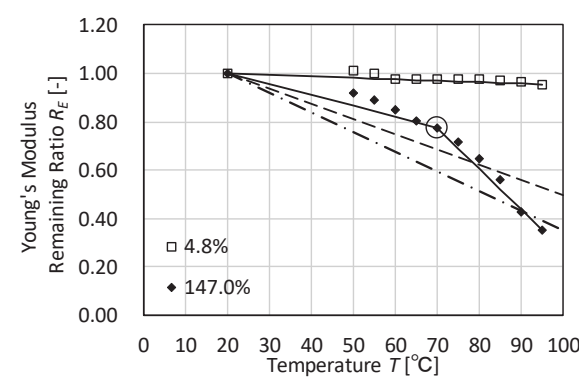

Chamaecyparis obtusa（ヒノキ)

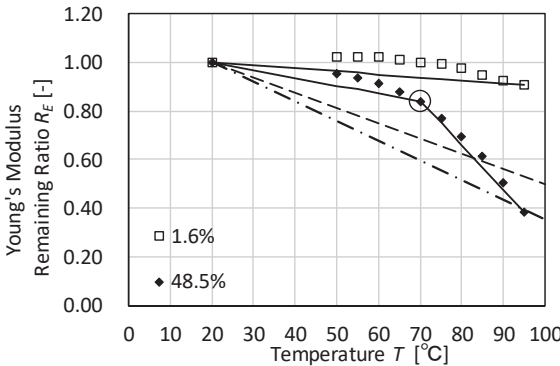

Picea sitchensis（スプルース）

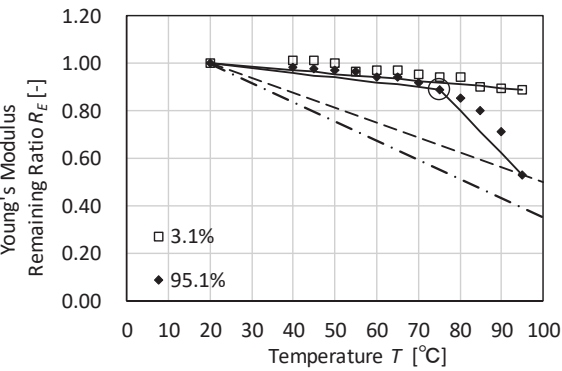

Castanea crenata（クリ）

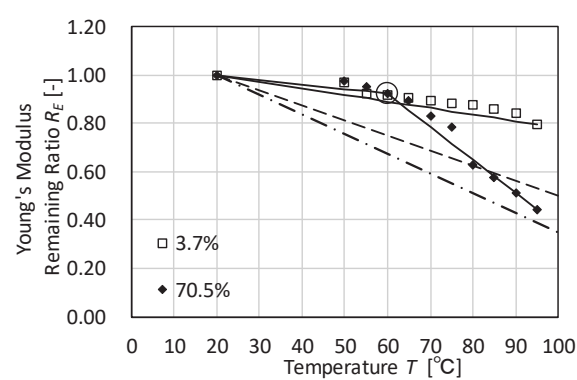

Larix leptolepis（カラマツ）

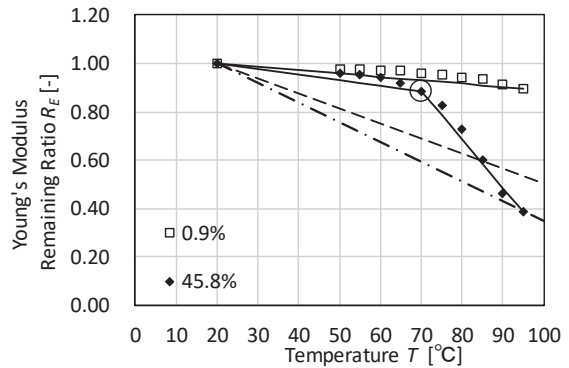

Tsuga mertensiana (ベイツガ)

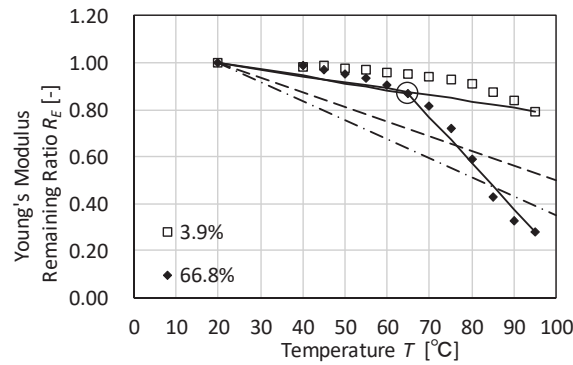

Quercus myrsinifolia（シラカシ）

Fig.4 Decrease of young's modulus remaining ratio $R_{E}$ with temperature increasing The values [\%] in figures mean moisture content of each specimens

飽水状態の試験体は、 $95^{\circ} \mathrm{C}$ 時に最小值がケヤキ 0.24 、最大値がク リ 0.53 となった。Fig.4 には Euro Code に示されたヤング係数残

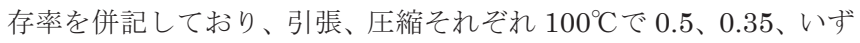
れも $300^{\circ} \mathrm{C}$ で 0 である 10 )。樹種により差異があるものの、いずれの 樹種も飽水状態、 $95^{\circ} \mathrm{C}$ 時には Euro Code の引張ヤング係数残存率を 下回っており、飽水状態ではヤング係数残存率が Euro Code 記載值 を下回る可能性があることとなる。飽水状態では、比較的低温から リグニンが軟化し、その後さらに高温でへミセルロースが軟化する こと ${ }^{13)}$ から、温度上昇に伴いヤング係数残存率の低下が急激になる ことが考えられる。実験結果も同様の傾向を示しているため、バイ リニアで近似することを試みた。Fig. 4 には、 $20^{\circ} \mathrm{C}$ と $95^{\circ} \mathrm{C}$ のング 係数残存率を結ぶバイリニアの近似線を点線で示している。近似線 は、 $20^{\circ} \mathrm{C}$ から $95^{\circ} \mathrm{C}$ の間の $5^{\circ} \mathrm{C}$ 刻みの温度がそれぞれ折れ点となった 場合の、実験值と近似線の二乗和を計算し、最も二乗和が小さかっ た温度を折れ点とした。折れ線は、実験值のヤング係数残存率と比 べ同等かそれ以下に推移しており、バイリニアでヤング係数残存率 の温度上昇による低下を表現できたと考えられる。ただし、温度上 昇時のヤング係数残存率は、バイリニアの近似線よりも若干高く推 移しており、実験值は上に凸の弓なりに低下寸る傾向があると考え られる。そのため、最大でクリ $85^{\circ} \mathrm{C}$ 時にヤング係数残存率 0.15 の
差が生じ、バイリニアで近似すると実際よりもヤング係数残存率が 若干低く計算される可能性がある。

また、熱軟化の影響が急激となる、バイリニアの近似線の折れ点 は各樹種により異なり、最低でベイマツ $55^{\circ} \mathrm{C}$ 、最大でケヤキ $80^{\circ} \mathrm{C}$ となった。

\section{4 回帰分析}

\section{1 分析方法}

\section{1 .1 回帰式}

基本式(2)を用いて、スギ、ヒノキ、カラマツ、ベイマツ及びケヤ キの 5 樹種の曲げ試験結果 2),3),6),11) 対象に回帰分析を行う。回帰分 析を行うため、 $D_{T}(T) 、 D_{M}(M) 、 D_{T M}(T, M)$ を温度、含水率の変化に よって表現する。 $D_{T}(T)$ は含水率は変化せず温度のみが变化した場 合、 $D_{M}(M)$ は温度は変化せず含水率のみが変化した場合、 $D_{T M}(T, M)$ は温度と含水率の双方が変化する場合のヤング係数残存率の低下率 を表す。なお、基本式(2)において $D_{T}(T) 、 D_{M}(M) 、 D_{T M}(T, M)$ は中 ング係数残存率の低下率として定義しているため、温度や含水率が 上昇した場合に正の值となる。

$D_{T}(T)$ は、Fig. 5 に示すように、温度上昇によりヤング係数残存率 が徐々に低下し、熱分解温度以降はさらに急激に低下寸るものと寸 
る。式(5)のようにバイリニアで表し、回帰分析において $T 、 T_{0}$ は実 験時の温度を代入し、 $d_{1} 、 d_{2} 、 T_{\text {decomp }}$ を変数とする。

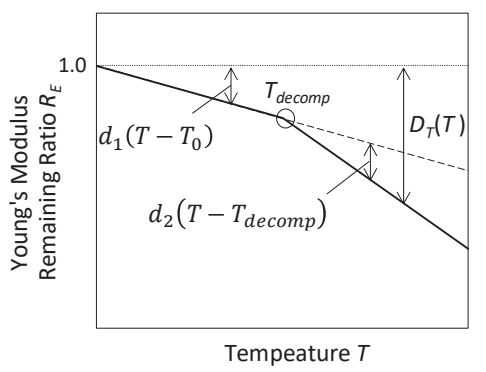

Fig.5 Definition of $D_{T}(T)$ in Formula (5)

$D_{T}(T)=d_{1}\left(T-T_{0}\right)+d_{2} \max \left\{0,\left(T-T_{\text {decomp }}\right)\right\}$

$T$ : Temperature after heating $\quad\left[{ }^{\circ} \mathrm{C}\right]$

$T_{0}:$ Initial temperature $\quad\left[{ }^{\circ} \mathrm{C}\right]$

$T_{\text {decomp }}$ : Decomposition Temperature $\quad\left[{ }^{\circ} \mathrm{C}\right]$

$d_{1}$ : Slope before decomposition $\quad\left[{ }^{\circ} \mathrm{C}^{-1}\right]$

$d_{2}$ : Slope after decomposition $\quad\left[{ }^{\circ} \mathrm{C}^{-1}\right]$

$D_{M}(M)$ は、繊維飽和点以下での含水率の増減のみがヤング係数残 存率を増減させるものとし、以下の式(6)で表す。ただし、回帰分析 の対象とする曲げ試験では、加熱中の含水率変化をできるだけ小さ く寸る目的で、試験体にアルミホイルを巻いた状態で加熱及び載荷 を行っている ${ }^{3), 6,11) 。 そ の た め 、 ~} D_{M}(M)$ を回帰分析の変数としても、 回帰分析では加熱前後の含水率の変化がヤング係数に及ぼす影響を 表現できない可能性が高い。よって、本研究では $D_{M}(M)$ を表す式(6) において、含水率変化時のヤング係数残存率の変化率を表す $d_{3}$ を 0 として回帰分析を行う。

本研究の回帰式を用いて、実際の部材で含水率が増減することの ヤング係数への影響を考慮するには、例えば文献 15 )では、含水率が $1 \%$ 上昇するとヤング係数が $0.90 \%$ 低下寸るとされており、 $d_{3}=$ 0.0090 として $D_{M}(M)$ を算出すればよい。

$D_{M}(M)=d_{3} \cdot\left(\min \{M, 30\}-\min \left\{M_{o}, 30\right\}\right)$

$d_{3}$ : Slope of changes of moisture content $\quad\left[\%^{-1}\right]$

$M_{0}$ : Initial moisture content [\%]

$M$ : Moisture content after heating [\%]

$D_{T M}(T, M)$ は、 $100^{\circ} \mathrm{C}$ 以下の範囲で、温度及び含水率の変化の相乗 効果でヤング係数残存率が変化することを意味し、式(7)で表現した。 式(7)では、Fig.6 に示すように、 $D_{T M}(T, M)$ を $D_{T M 1}(T, M)$ と $D_{T M 2}(T)$ の最小值として表現した。

まず、 $D_{T M 1}(T, M)$ は、木材中のリグニン及びヘミセルロースが 40 $\sim 60^{\circ} \mathrm{C}$ 付近に軟化点を持ち、軟化点以降では高温時の力学的性能の 含水率依存性が上昇寸る ${ }^{12)}$ ため、軟化点以上では高温・高含水率に なるほど力学的性能が低下寸るものとし、 $D_{T M 1}(T, M)$ を式(8)で表 した。ただし、常温時は繊維飽和点以上では力学的性能が含水率に 依存しないように、高温時においても熱軟化による力学的性能の低
下の限界が現れると考えられる。そこで、 $D_{T M 2}(T)$ を熱軟化による ヤング係数残存率の限界として、式(9)で定義した。その際、飽水状 態で温度上昇した時のヤング係数残存率は、3 章の温度漸増曲げ試 験の実験結果(Fig.4)から、温度上昇に対して線形に低下せず、樹種 により傾向も異なることがわかっている。よって、 $D_{T M 2}(T)$ を Fig.4 と同様にバイリニアで表現した。式(9)の形は、熱分解時以降力学的 性能の低下が急激になるように温度依存性を定義した式(5)、Fig.5 と同様である。

以上より、回帰分析では $T 、 T_{0} 、 M 、 M_{0}$ は実験時の温度を代入 し、 $d_{4} 、 d_{5} 、 d_{6} 、 T_{s 1} 、 T_{s 2}$ を変数とする。

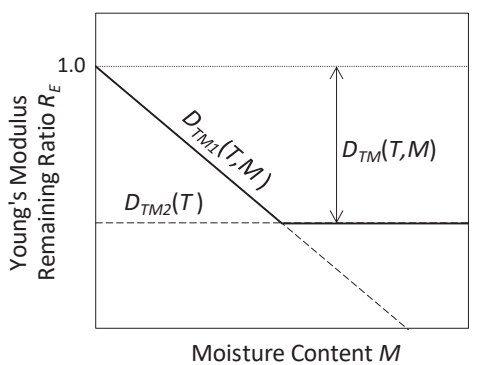

Fig.6 Definition of $D_{T M}(T, M)$ in Formula (7)

$D_{T M}(T, M)=\min \left\{D_{T M 1}(T, M), D_{T M 2}(T)\right\}$

$D_{T M 1}(T, M)=d_{4} \cdot M \cdot \max \left\{0,\left(\min \{T, 100\}-T_{s 1}\right)\right\}$

$d_{4}$ : Slope of thermal softening $\left[\left({ }^{\circ} \mathrm{C} \cdot \%\right)^{-1}\right]$

$T_{s 1}$ : First Thermal softening temperature $\left[{ }^{\circ} \mathrm{C}\right]$

$D_{T M 2}(T)=d_{5}\left(T-T_{0}\right)+d_{6} \max \left\{0,\left(T-T_{s 2}\right)\right\}$

$d_{5}:$ Slope before $T_{s 2}$

$\left[{ }^{\circ} \mathrm{C}^{-1}\right]$

$d_{6}$ : Slope after $T_{s 2}$

$\left[{ }^{\circ} \mathrm{C}^{-1}\right]$

$T_{s 2}$ : Second thermal softening temperature $\left[{ }^{\circ} \mathrm{C}\right]$

\section{1 .2 各係数の決定方法}

ヤング係数残存率を計算する基本式(2)、及びその各項を定義した 式(5)〜 (9)中の各係数を回帰分析により決定する。目的変数はヤング 係数残存率のみであるのに対し、説明変数である式(5)〜 (9)中の各係 数が複数であるため、重回帰分析により各係数を決定する。すなわ ち、計 8 つの係数 $\left(d_{1}, d_{2}, d_{4}, d_{5}, d_{6}, T_{\text {decomp }}, T_{s 1}, T_{s 2}\right)$ を変化させた 時に、実験值と回帰式が計算するヤング係数残存率の差の二乗和が 最小となるように重回帰分析を行う。

具体的には、式(5) (9) 中に $T 、 T_{0} 、 M 、 M_{0}$ は実験時の值を、重 回帰分析の対象となる計 8 つの係数は初期值として 0 を代入し、 $D_{T}(T) 、 D_{M}(M) 、 D_{T M}(T, M)$ を算出する。基本式(2)に算出された $D_{T}(T)$ 、 $D_{M}(M) 、 D_{T M}(T, M)$ を代入し、ヤング係数残存率 $R_{E}$ の計算值が求ま る。重回帰分析では計 8 つ係数を変化させ、 $R_{E}$ の計算值と実験值 の差の全試験体の二乗和の最小化を行う。なお、重回帰分析で目的 変数とするヤング係数残存率の実験值は、Table1 中で対象としてい る既報 2),3,66),11実験結果のみである。3 章の温度漸増曲げ試験の実験 結果は式(9)の $D_{T M 2}(T, M)$ の表現方法の決定のみに用いており、重回 帰分析の係数の決定には用いていない。 


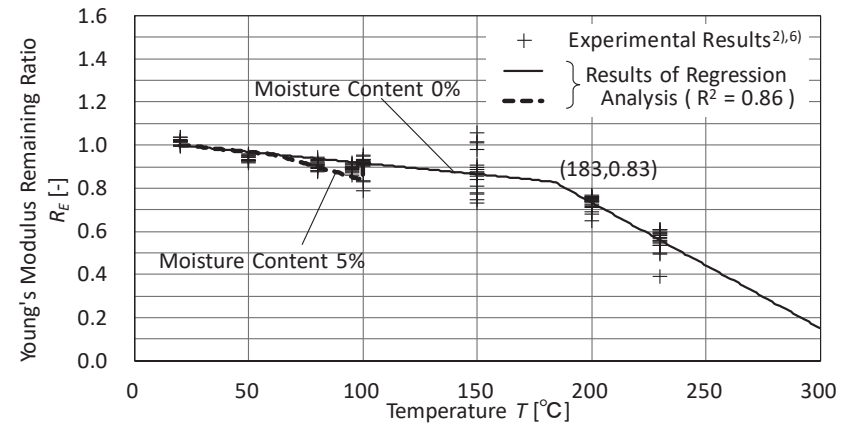

Cryptomeria japonica, スギ

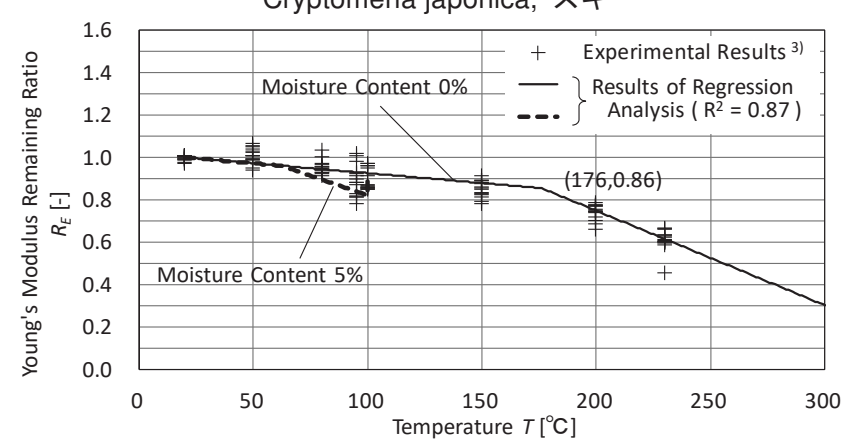

Chamaecyparis obtusa, ヒノキ

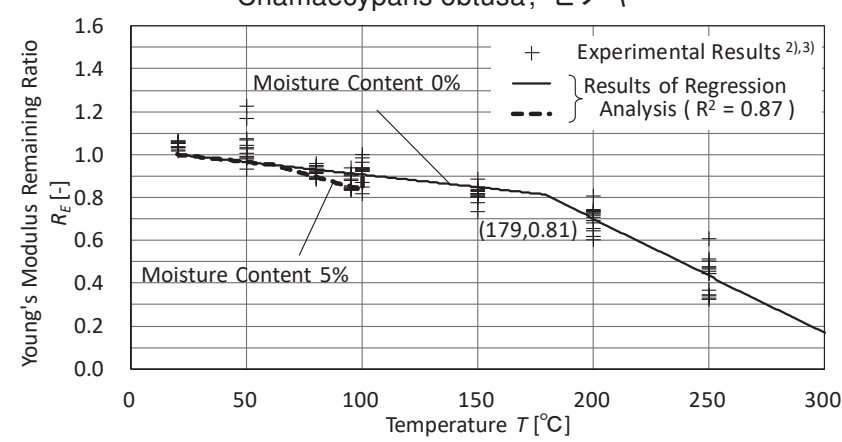

Larix leptolepis，カラマッ

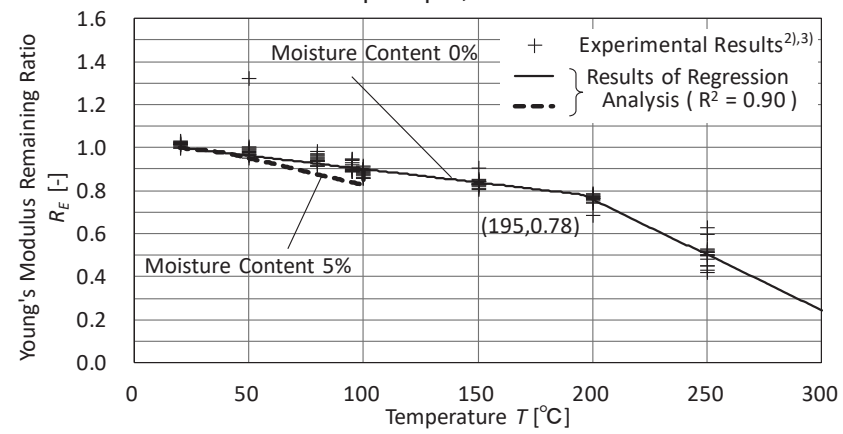

Pseudotsuga menziesii, ベイマッ

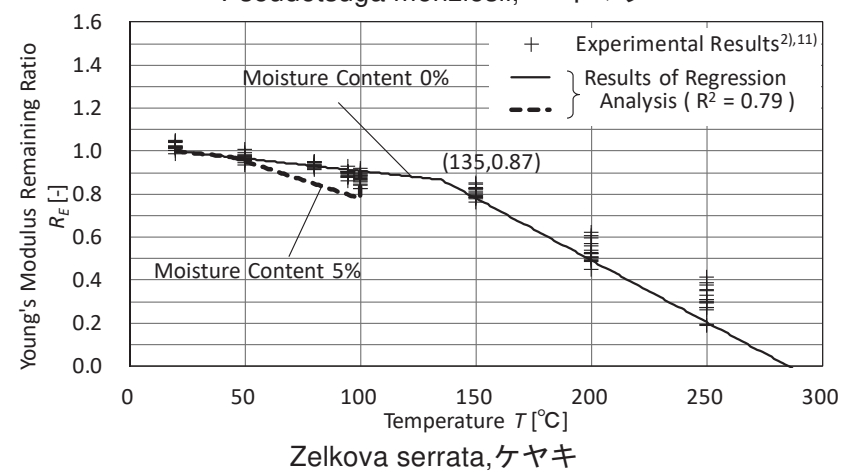

Fig.7 Temperature vs. Young's modulus remaining ratio $R_{E}$ at moisture content under $5 \%$

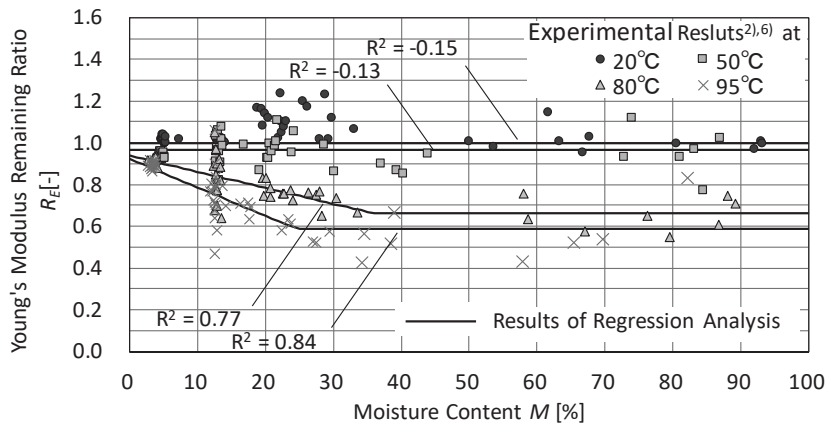

Cryptomeria japonica, スギ

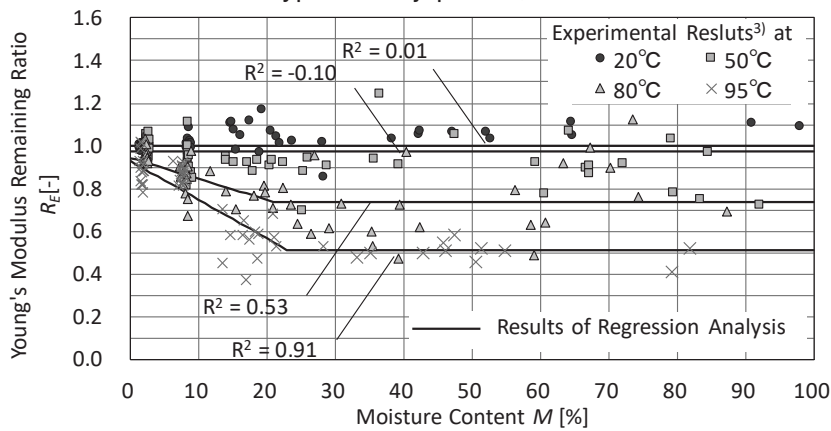

Chamaecyparis obtusa, ヒノキ

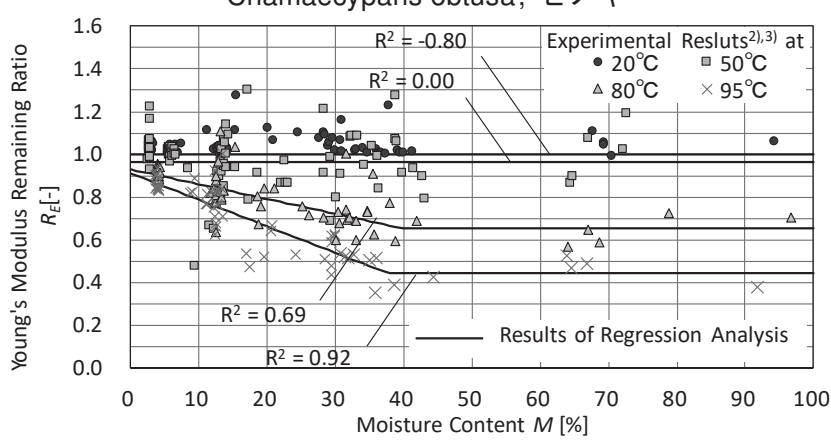

Larix leptolepis，カラマッ

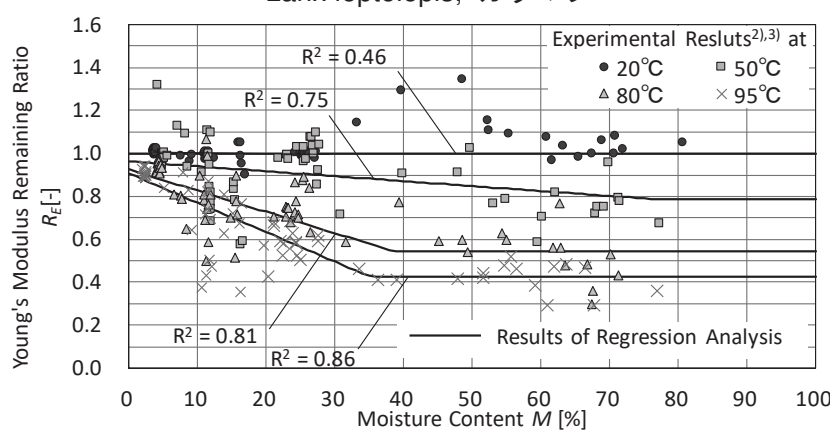

Pseudotsuga menziesii, ベイマッ

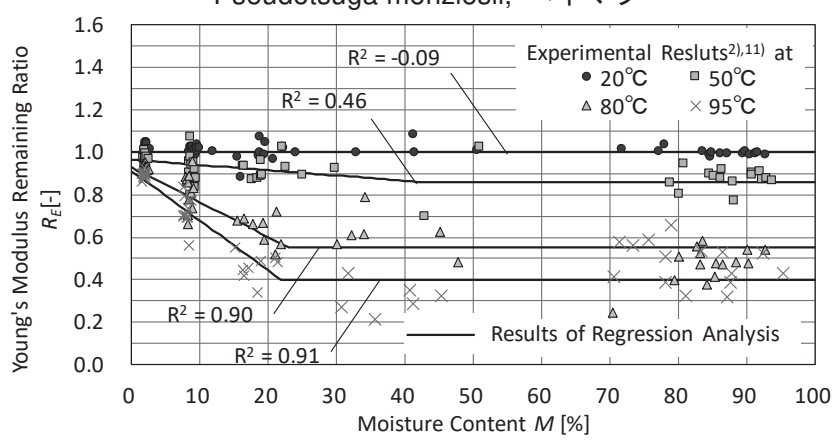

Zelkova serrata,ケヤキ

Fig. 8 Moisture content vs. Young's Modulus remaining ratio 


\section{2 回帰分析結果と考察}

\section{2 .1 分析結果}

Table3 に回帰分析結果の係数を、Fig.7、Fig.8 に回帰分析の結果 と実験結果との比較を図示している。Fig.7 は含水率 $5 \%$ 以下におけ る温度とヤング係数残存率の関係を示し、Fig. 8 は $100^{\circ} \mathrm{C}$ 以下の範 囲で温度ごとの含水率とヤング係数残存率の関係を示している。

Fig.7、Fig.8 ともに実験結果をプロットで示し、実線・点線で回帰 分析の結果を示している。Fig7,8 中の回帰分析の結果を示す実線・ 点線には、温度・含水率とヤング係数残存率の関係を回帰式により 表現できているか評価するため、決定係数( $\mathrm{R}^{2}$ 值)を併記した。

Fig.7 において、実線は含水率 $0 \%$ 、点線は含水率 $5 \%$ の回帰分析 結果を示している。試験体の含水率は $0 \sim 5 \%$ であるため、試験体の 温度、含水率から計算されたヤング係数残存率は実線と点線の範囲 内に存在する。含水率 $0 \%$ の回帰分析結果である実線において、温 度上昇時にヤング係数残存率が急激になる温度が $T_{\text {decomp }}$ 、その前後 の勾配がそれぞれ $d_{1}$ 及び $d_{1}+d_{2}$ である。含水率がある場合、熱軟 化温度 $T_{S 1}$ を超えると含水率依存性が増加、寸なわち $D_{T M}(T, M)$ が 生じるため、式( 8 ) 中の $d_{4} \cdot M$ 分だけさらに勾配が生じる。よって、 含水率 $5 \%$ の回帰分析結果である点線は、熱軟化温度 $T_{s 1}$ 以上 $100^{\circ} \mathrm{C}$ 以下の範囲で実線よりも傾きが急になり、その勾配は $d_{1}+d_{4} \cdot M$ と なっている。重回帰分析の係数決定過程において、温度依存性を示 す $d_{1}$ は、 $5 \%$ 以下の比較的低含水率であっても高温時の含水率依存 性の増加分 $d_{4} \cdot M$ を差し引いて算出されていることとなる。 $T_{\text {decomp }}$ は全ての樹種で $100^{\circ} \mathrm{C}$ 以上であるため $d_{2}$ は含水率の影響を受けず、 Table1 の 100 250 $\mathrm{C}$ の実験結果から算出されていることとなる。

Fig.8 において、含水率が上昇したときにヤング係数残存率の低 下が生じ始める温度が $T_{s 1}$ 、その低下の勾配が $d 4$ 、含水率上昇時に ヤング係数残存率が横ばいとなるときの低下量が $D_{T M 2}(T)$ である。 $D_{T M} 2(T)$ は Fig. 9 に示寸ように、温度上昇時にヤング係数残存率が 急激になる温度が $T_{s 2}$ 、その前後の勾配がそれぞれ $d_{5}$ 及び $d_{5}+d_{6}$ で ある。Fig. 8 の含水率 $0 \%$ の時のヤング係数残存率の低下量が $D_{T}(T)$ であり、重回帰分析の係数決定過程において、高温時の含水率依存 性を示す $d_{4} 、 d_{5} 、 d_{6}$ 、及び高温時に含水率依存性が増大し始める温 度を示寸 $T_{s 1} 、 T_{s 2}$ は、全乾状態の温度上昇によるヤング係数残存率 の低下量 $D_{T}(T)$ を差し引いて算出されていることとなる。

\subsection{2 全乾状態の温度依存性}

Fig.7 では、全乾状態における温度上昇時のヤング係数残存率の

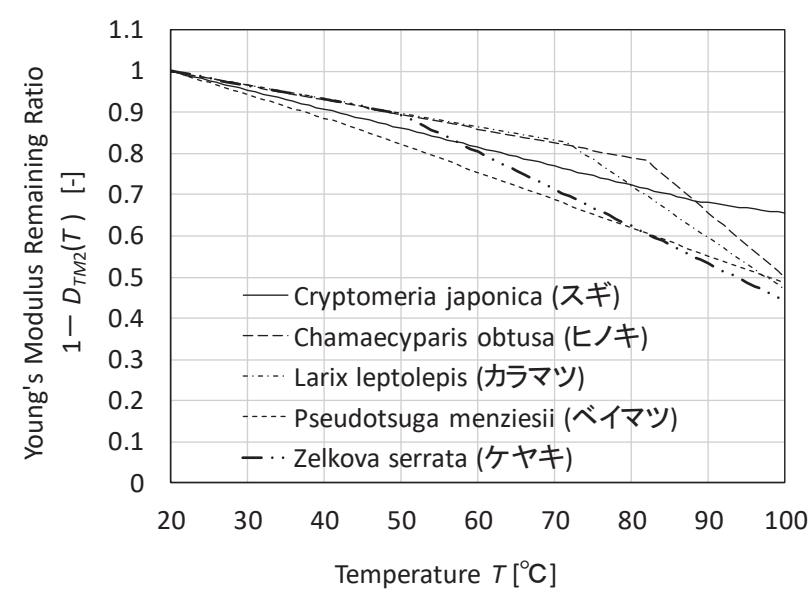

Fig.9 Temperature vs. $1-D_{T M_{2}}(T)$ in Formula (9)

低下は熱分解の開始温度付近から急激になると仮定して回帰分析を 行った結果、決定係数はケヤキが最低で 0.79 となった。ヤング係数 残存率の低下が急激となる温度とした $T_{\text {decomp }}$ は、針葉樹ではヒノキ $176.1^{\circ} \mathrm{C}$ 〜゙イマツ $195.6^{\circ} \mathrm{C}$ と、熱分解の開始温度である $180^{\circ} \mathrm{C}$ 付近 14)であり、熱分解がヤング係数の急激な低下の要因となっていると 考えられる。一方、ケヤキでは $T_{\text {decomp }}$ は $135.1^{\circ} \mathrm{C}$ と、針葉樹に比心 明らかに低く、広葉樹では針葉樹よりも全乾状態の温度依存性が比 較的低温から急激に低下寸る傾向を有する可能性がある。

なお、木材の炭化温度は約 $260^{\circ} \mathrm{C}$ であるが 1)、本研究では炭化に ついては回帰分析時に考慮していない。そのため、本研究の回帰分 析結果ではケヤキを除いて $300^{\circ} \mathrm{C}$ でヤング係数残存率は 0 以上であ る。炭化した領域に荷重支持能力は期待できないと考えると、本回 帰分析結果を力学的性能の予測・評価に用いる際は、炭化温度以降 はヤング係数残存率を 0 とする必要がある。

\subsection{3 $100^{\circ} \mathrm{C}$ 以下の温度依存性及び含水率依存性}

Fig.8 は含水率とヤング係数残存率の関係を示しており、回帰分 析対象の曲げ試験 2),3),6),11)が行われている $20,50,80,95^{\circ} \mathrm{C} の$ 実験結果 と回帰分析結果を示した。

いずれの樹種も、高含水率状態によりヤング係数残存率の温度依 存性が増加すると仮定した $T_{s 1}$ 以下の温度では、含水率によらずヤ ング係数残存率は一定である。 $\mathrm{R}^{2}$ 值はカラマツ $20^{\circ} \mathrm{C}$ で最低- 0.80 、 ベイマツ $20^{\circ} \mathrm{C}$ で最高 0.46 と著しく低く、 $T_{s 1}$ 以下の温度では含水率 とヤング係数残存率に相関がないことを意味している。

Table3 Constants resulted in regression analysis

Tree species

\begin{tabular}{|c|c|c|c|c|c|c|c|c|c|c|c|}
\hline \multicolumn{3}{|c|}{ Tree species } & \multicolumn{9}{|c|}{ Constants resulted in regression analysis } \\
\hline \multirow{3}{*}{$\begin{array}{l}\text { Hard wood } \\
\text { or } \\
\text { Soft wood }\end{array}$} & \multirow{3}{*}{$\begin{array}{l}\text { Scientific } \\
\text { name }\end{array}$} & \multirow{3}{*}{$\begin{array}{c}\text { Japanese } \\
\text { name }\end{array}$} & \multicolumn{3}{|c|}{$D_{T}(T)$} & \multirow{3}{*}{$\begin{array}{c}\frac{D_{M}(M)}{d_{3}^{* 1}} \\
{\left[10^{-3} \cdot \%^{-1}\right]}\end{array}$} & \multicolumn{5}{|c|}{$D_{T M}(T, M)$} \\
\hline & & & & $d_{2}$ & $T_{\text {decomp }}$ & & $d_{4}$ & $d_{5}$ & $d_{6}$ & $T_{s 1}$ & $T_{s 2}$ \\
\hline & & & {$\left[10^{-3} \cdot{ }^{\circ} \mathrm{C}\right.$} & $\left.{ }^{-3} \cdot{ }^{\circ} \mathrm{C}^{-1}\right]$ & {$\left[{ }^{\circ} \mathrm{C}\right]$} & & {$\left[10^{-4} \cdot\left({ }^{\circ} \mathrm{C} \cdot 0\right.\right.$} & $\left.{ }^{-1}\right]\left[10^{-3} \cdot{ }^{\circ} \mathrm{C}\right.$ & $\left.{ }^{-1}\right]\left[10^{-3} \cdot{ }^{\circ} \mathrm{C}^{-1}\right]$ & {$\left[{ }^{\circ} \mathrm{C}\right]$} & {$\left[{ }^{\circ} \mathrm{C}\right]$} \\
\hline \multirow{4}{*}{ Soft Wood } & Cryptomeria japonica & スギ & 1.04 & 4.79 & 183.4 & 0.00 & 3.93 & 4.61 & -2.06 & 60.5 & 88.3 \\
\hline & Chamaecyparis obtusa & ヒノキ & 0.928 & 3.52 & 176.1 & 0.00 & 5.56 & 3.50 & 12.28 & 62.3 & 82.0 \\
\hline & Pseudotsuga menziesii & ベイマツ & 1.25 & 3.89 & 195.6 & 0.00 & 2.53 & 5.72 & 1.04 & 40.9 & 44.2 \\
\hline & Average of Soft wood & - & 1.10 & 4.09 & 183.4 & 0.00 & 3.92 & 4.30 & 5.14 & 56.2 & 71.6 \\
\hline Hard wood & Zelkova serrata & ケヤキ & 1.16 & 4.61 & 135.1 & 0.00 & 4.65 & 3.43 & 5.59 & 44.7 & 49.4 \\
\hline
\end{tabular}

${ }^{* 1} d_{3}$ had been set to 0 because changes of moisture content between before and after heating was few during bending tests for regression analysis 


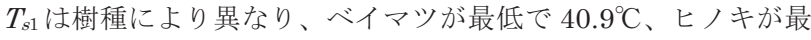
高で $62.3^{\circ} \mathrm{C}$ となった。いずれの樹種においても、温度上昇に伴い高 温・高含水率時のヤング係数残存率の低下が顕著になるため、高温 になるほど $\mathrm{R}^{2}$ 值は増加している。 $95^{\circ} \mathrm{C}$ 時には、最低でスギ 0.84 、 最高でカラマツ 0.92 と、高温・高含水率状態のヤング係数残存率の 低下をよく表現できていると考えられる。ただし、高温時・飽水状 態のヤング係数残存率の低下量を表す $D_{T M 2}(T)$ は、3 章の温度漸増 曲げ試験の結果(Fig.4)から温度上昇時に $T_{s 2}$ を超えるとより急激に ヤング係数残存率が低下寸ると仮定したが、Fig.9 に示寸ようにス ギ、ベイマツではほぼ直線的に低下寸る結果となった。スギについ ては、 $d_{6}$ が負の值となり、 $T_{s 2}$ 以上の温度では若干低下が緩やかとな っている。これらの樹種ごとの差異はリグニン及びヘミセルロース の含有量の差異に起因すると考えられ、樹種によっては必ずしも温 度上昇に伴い飽水状態のヤング係数残存率の含水率依存性の低下が 顕著にならない場合も存在することがわかった。

高温・高含水率状態によりヤング係数残存率が最も低下している $100^{\circ} \mathrm{C}$ ・飽水状態のヤング係数残存率は、スギ 0.57 (含水率 $23 \%$ 以上 の時)、ヒノキ 0.42 (含水率 $24 \%$ 以上の時)、カラマツ 0.37 (含水率 $38 \%$ 以上の時)、ベイマツ 0.38 (含水率 $35 \%$ 以上の時)、ケヤキ 0.35 (含水 率 $30 \%$ 以上の時) となっている。Fig.5 の全乾状態のヤング係数残存 率と比較すると、いずれの樹種でも全乾状態・ $200^{\circ} \mathrm{C}$ のヤング係数残 存率を下回っており、高温・高含水率となることのヤング係数残存 率一の影響は大きいと考えられる。加えて、 $100^{\circ} \mathrm{C}$ 以下で高温時にな るほど含水率が上昇した際のヤング係数残存率の低下が急激となる こと、及び火災加熱を受ける部材内部では水分の蒸発潜熱により $100^{\circ} \mathrm{C}$ 付近で温度が停滞する領域が存在することから、部材内部で 含水率の力学的性能一の影響を明らかにする重要性が改めて示され た。

\section{3 回帰式の樹種による差異と他樹種への適用可能性}

本研究で回帰分析の対象としていない樹種についても、回帰式を 用いて温度・含水率からヤング係数残存率を予測できる可能性を検 討するため、回帰分析結果の係数を樹種ごとに比較する。ただし、 広葉樹についてはケヤキの 1 樹種のみで比較が困難なため、針葉樹 の 4 樹種を考察の対象とする。Table3 には、各係数の針葉樹 4 樹種 の平均值を示している。

まず、全乾状態の温度依存性に関して、熱分解の開始温度と仮定 した $T_{\text {decomp }}$ は平均值が $182.6^{\circ} \mathrm{C}$ であり、 4 樹種の值は平均值から士 $10^{\circ} \mathrm{C}$ の間に収まっており、樹種による違いは小さい。温度上昇時の ヤング係数残存率の低下率を示す $d_{1} 、 d_{2}$ についても、平均值と比 較して、 $d_{1}$ はヒノキ $-15.4 \%$ ベイマツ $+13.6 \% 、 d_{2}$ は-13.9\%〜ベ イマツ $+17.1 \%$ と、 $\pm 20 \%$ 程度の範囲に収まっており、他の針葉樹の 温度依存性は平均值を用いれば傾向的に予測できる可能性がある。

一方、 $100^{\circ} \mathrm{C}$ 以下の範囲の温度・含水率依存性に関して、熱軟化を 生じはじめる $T_{s 1}$ は、スギ、ヒノキ及びカラマツが約 $60^{\circ} \mathrm{C}$ であるの に対し、ベイマツは約 $40^{\circ} \mathrm{C}$ と、低温から熱軟化を生じている。含水 率上昇時のヤング係数残存率の低下率を示寸 $d_{4}$ についても、平均 值と比較してベイマツー $35.6 \%$ ヒノキ $+41.6 \%$ と、大きな差異を 生じている。飽水状態のヤング係数残存率の低下量を示寸 $D_{T M 2}(T)$ についても、Fig.9 に示すように低下傾向が樹種により異なり、 $100^{\circ} \mathrm{C}$ 時にはスギとカラマッで最大 0.19 の差を生じている。よって、 $100^{\circ} \mathrm{C}$ 以下の範囲の含水率依存性は、樹種により傾向が異なり、本回 帰分析結果から他の針葉樹のヤング係数残存率を予測することは困 難と考えられる。

以上より、針葉樹のヤング係数残存率の樹種による差異は、 $250^{\circ} \mathrm{C}$ 以下における全乾状態の温度依存性については比較的小さいが、 $100^{\circ} \mathrm{C}$ 以下の含水率依存性については大きいことが分かった。今後、 既報 $33,6,11)$ と同様の実験等により $100^{\circ} \mathrm{C}$ 以下の含水率依存性を定め る係数が同定できれば、本研究の回帰式・回帰分析結果の係数を用 いて他の針葉樹のヤング係数残存率を予測できる可能性がある。

\section{5 総括}

本研究では、まず全乾状態及び飽水状態の小試験体の昇温時のヤ ング係数の低下を、 $95^{\circ} \mathrm{C}$ 以下の範囲で曲げ試験により調查し以下 の知見を得た。

（1）全乾状態に比べ飽水状態では温度上昇に伴いヤング係数は著し く低下し、飽水状態・ $95^{\circ} \mathrm{C}$ 時の常温時と比べたヤング係数の残存 率は $0.24 \sim 0.53$ まで低下した。

（2）全乾状態で、熱分解に達しない範囲であれば温度上昇時に直線 的にヤング係数が低下寸るが、飽水状態では木材中の物質が軟化を 迎える温度付近から急激にヤング係数が低下した。その温度は樹種 ごとに異なり、55〜 $80^{\circ} \mathrm{C}$ となった。

これらの実験結果及び既往 1) 3),12),13)の知見を用いてヤング係数の 残存率を温度と含水率で表現する回帰式を作成した。回帰式の係数 を決定するため、既報 2),3),6),11)の曲げ試験結果のうち 5 樹種(針葉樹 のスギ、ヒノキ、カラマツ、ベイマツ、及び広葉樹のケヤキ)を対 象として回帰分析を行い、以下の知見を得た。

（3）温度及び含水率を引数として、ヤング係数の残存率を算出する 式を導出した。実験結果と比較して算出した決定係数は、最も低い 值で、全乾状態の温度依存性については $0.79 、 95^{\circ} \mathrm{C}$ 時の含水率依 存性については 0.84 と、木材の温度と含水率によるヤング係数残 存率の低下を精度よく表現できた。

（4）全乾状態では、温度上昇に伴いヤング係数残存率は低下し、熱 分解開始温度を超えるとより急激になる。熱分解開始温度は針葉樹 で約 $180^{\circ} \mathrm{C}$ 、広葉樹はケヤキが約 $135^{\circ} \mathrm{C}$ となっ。 $100^{\circ} \mathrm{C}$ 以下にお いても、高含水率時には温度依存性が増加し、本研究の分析結果で は $100^{\circ} \mathrm{C}$ で飽水状態のヤング係数残存率は最低でケヤキ 0.35 まで 低下した。

（5）針葉樹のヤング係数残存率は、 $250^{\circ} \mathrm{C}$ 以下における全乾状態の 温度依存性については樹種による差異が小さいものの、 $100^{\circ} \mathrm{C}$ 以下 の比較的低温でも温度上昇時の含水率依存性の変化や高温・高含水 率によりヤング係数残存率が低下寸る下限值に差異が生じることが わかった。

今後は、火災加熱を受ける木質部材内部の熱・水分移動状況を把 握し、本研究で提案したヤング係数残存率の計算式を用いて木質部 材の含水率の力学的性能への影響を明らかにすることが望まれる。 また、ヤング係数のみならず圧縮強度や曲げ強度の含水率の影響の 定量化や、国際的にも多様に存在寸る他の樹種について検討を行う ことが課題である。 


\section{謝辞}

本研究内で行った実験は、科学研究費基盤研究「大断面木質部材 の防耐火性能設計の工学モデル」及び「大規模居室における内装の 燃焼拡大性状の予測と火災規模の局限化に関する研究」(いずれも 代表研究者 : 長谷見雄二)の一環として行いました。記して深く感 謝申し上げます。

\section{参考文献}

1) Forest Products Laboratory : Wood Handbook, Capter 18, pp.18-8 1814,2010

2) Kaku, C. Hasemi, Y. Yasui, N. Yasukawa, M. Kamikawa, D. Kameyama, N. Ono, T. Koshihara, M. and Nagao, H.: Influence of Fire Exposure on the Mechanical Properties of Wood -Exposure temperature dependence of Young's modulus and bending strength of Cryptomeria japonica, Larix leptolepis,Pseudotsuga menziesii and Zelkova serrata under and after heating-, Journal of Structural and Construction Engineering (Transactions of AIJ), Vol.79, No.701, pp.1065-1072, 2014.7 (in Japanese)

加來千紘, 長谷見雄二, 安井昇, 保川みずほ,上川大輔, 亀山直央, 小野徹郎, 腰 原幹雄, 長尾博文 : 火災加熱が木材の力学的性能に及ぼす影響 一加熱した 針葉樹材及び広葉樹材の高温時及び加熱泠却後のヤング係数・曲げ強度の 測定一, 日本建築学会構造系論文集, 79 巻,701 号,pp.1065-1072,2014.7

3) Watanabe, S. Suzuki, T. Hasemi, Y. Kaku, C. Kamikawa, D. Yasui, N. Miyamoto, K. : Dependence of the Mechanical Properties of Wood on Temperature, Moisture Content and Tree Species at Elevated Temperatures -Measurement of Young's modulus and bending strength on major structural tree species and examination of the predictability of the mechanical properties at elevated temperatures based on basic material properties- , Journal of Structural and Construction Engineering (Transactions of AIJ), Vol.84, No.761, pp.1011-1020, 2019.7 (in Japanese)

渡辺秀太, 鈴木達朗, 長谷見雄二, 加來千紘, 上川大輔, 安井昇, 宮本康 太 : 多様な樹種の木材の力学的性能に対する温度 - 含水率の影響の把握と 予測可能性一構造用主要樹種に関するデー夕構築と全乾密度に基づく予測 可能性の検討一, 日本建築学会構造系論文集, 84 巻,761 号,pp.10111020,2019.7

4) Ishii, S. Igarashi, T. Shigeaki, B. Kataoka, T. Someya, T. Hirashima, T. : Deformation Behavior and Failure Time of Structural Glulam Timbers Exposed to Standard Fire Heating :Part 5 Analysis of Load Bearing Fire Tests of Larch Glulam Timber Columns, Summaries of Technical Papers of Annual Meeting, Architectural Institute of Japan, Fire Safety, pp.259260, 2018.7 (in Japanese)

石井俊吾, 五十嵐樹, 馬場重彰, 片岡辰幸, 染谷朝幸, 平島岳夫 : 標準火 災加熱を受ける構造用集成材の変形挙動および破壊時間（その 5), カラマ ツ構造用集成材による柱の載荷加熱実験に関する解析, 日本建築学会大会 学術講演梗概集，防火, pp.259-260, 2018.7

5) Yasui, N. Shimizu, M. Hasemi, Y. Murakami, M. Kamijima, M. Kimura, T. Hokugo, A. Tamura, Y. Yoshida, M. Yamamoto, K. : Prediction and Design of Mechanical Fire Resistance of Japanese Traditional Wood/Soil Walls by Compression Tests of Wood Posts, Journal of Environmental Engineering (Transactions of AIJ), No.574, pp.1-6, 2003.12 (in Japanese)

安井昇, 清水真理子, 長谷見雄二, 村上雅英, 上島基英, 木村忠紀, 北後明 彦，田村佳英，吉田正友，山本幸一: 柱圧縮試験による木造土壁の火災加熱 時の非損傷性予測と木造土壁外壁の防火設計, 日本建築学会環境系論文集 574 号, pp.1-6, 2003.12.

6) Suzuki, T. Kaku, C. Hasemi, Y. Kamikawa, D. Yasui, N. Kameyama, N. Koshihara, M. and Nagao, H.: Influence of Water Content on the Mechanical Properties of Wood under Heating Part1: Exposure temperature and Water Content dependence of Young's modulus and bending strength of cedar, Summaries of Technical Papers of Annual Meeting, Architectural Institute of Japan, Fire Safety, pp.135-138, 2015.7 (in Japanese)

鈴木達朗, 加來千紘, 長谷見雄二, 上川大輔, 安井昇, 亀山直央, 腰原幹雄, 長尾博
文：木材の含水率が高温時の力学的性能に及ぼす影響 : (その 1)針葉樹材 (スギ)の高温時ヤング係数・曲げ強度の把握, 日本建築学会大会学術講演梗 概集，防火, pp.135-138, 2015.7

7) Fredlund, B. : A Model for Heat and Mass Transfer in Timber Structures During Fire, Lund University Sweden, 1985, Ph.D. thesis

8) White R. H. and Schaffer E. L. : Transient Moisture Gradient in Fireexposed Wood Slab, Wood and Fiber, Society of Wood Science and Technology, Vol.13, No.1, pp.17-38, 1981.1

9) Namiki, J. Hasemi, Y. Watanabe, S. Suzuki, T. Takase, R. Kaku, C. : Dynamic Measurement of Moisture Content within small Cedar Specimen Exposed to Fire Heating, Summaries of Technical Papers of Annual Meeting, Architectural Institute of Japan, Fire Safety, pp.185186, 2019.7 (in Japanese)

並木淳，長谷見雄二，渡辺秀太，鈴木達朗，高瀬椋，加來千紘：火災加熱を 受ける小型スギ試験体内部の含水率の動的測定に関する研究, 日本建築学 会大会学術講演梗概集，防火,pp.185-186, 2019.7

10) BS EN1995-1-2: 2004, Eurocode 5 Design of timber structures, Part12: General-Structural fire design

11) Kaku, C., Suzuki, T., Hasemi, Y., Kamikawa, D., Yasui, N., Kameyama, N., Koshihara, M., Nagao, H.: Influence of Moisture Content of Wood on Mechanical Property at High Temperature (Part 2) Grasping Young's Modulus and Bending Strength of hardwood ( Zelkova serrata ) at High Temperature, Summaries of Technical Papers of Annual Meeting, Architectural Institute of Japan, Fire Safety, pp.121-122, 2015.7 (in Japanese)

加來千紘, 鈴木達朗, 長谷見雄二, 上川大輔, 安井昇, 亀山直央, 腰原幹雄, 長尾博文：木材の含水率が高温時の力学的性能に及ぼす影響 (その 2) 広葉 樹材 (ケヤキ) の高温時ヤング係数・曲げ強度の把握, 日本建築学会大会学 術講演梗概集，防火, pp.121-122, 2015.7

12) Forest Products Laboratory : Wood Handbook, Capter 18, pp.5-34 536,2010

13) Furuta, Y.: Thermal-Softening Properties of the Water-Swollen Wood, Wood Industry, Kyoto university, Ph.D. Thesis, 1998.3 (in Japanese) 古田裕三: 飽水状態の木材の熱軟化特性, 京都大学博士論文, 1998.3

14) Kuriyama, A. : On the Changes in the Chemical Composition of Wood within the Temperature Range up to $200{ }^{\circ} \mathrm{C}$, Journal of the Society of Material Science, Japan, Vol.16, No.169, pp.772-776, 1967.10 (in Japanese)

栗山旭：木材の $200^{\circ} \mathrm{C}$ までの加熱処理による化学的変化について, 材料, 日本材料学会, 第 16 巻, 169 号, pp.772-776, 1967.10

15) Forestry and Forest Products Research Institute Supervision: Wood Industry Hand Book, p268, Maruzen, 2004.3 (in Japanese) 森林総合研究所監修: 木材工業ハンドブック、p268、丸善、2004.3 revised 


\title{
DEVELOPMENT OF AN EQUATION CALCULATING YOUNG'S MODULUS REMAINING RATIO WITH TEMPERATURE AND MOISTURE CONTENT WITHIN WOODEN MEMBERS EXPOSED TO FIRE HEATING
}

\author{
Tatsuro SUZUKI*1, Yuji HASEMI*2, Daisuke KAMIKAWA*3, \\ Noboru YASUI ${ }^{* 4}$, Chihiro KAKU ${ }^{* 4}$ and Shuta WATANABE* ${ }^{* 5}$ \\ ${ }^{* 1}$ Technology Center, Taisei Corp., M.Eng. (Formerly Waseda Univ.) \\ ${ }^{*}$ Prof., Faculty of Science and Engineering, Waseda Univ., Dr.Eng. \\ ${ }^{*}$ Forestry Research and Management Organization, Ph.D. \\ ${ }^{*}$ Adjunct Researcher, WISE, Waseda Univ., Ph.D. \\ ${ }^{* 5}$ Sumitomo Forestry Corporation, M.Eng. (Formerly Waseda Univ.)
}

Young's Modulus of wood at elevated temperatures is formulated as functions of temperature and moisture content for the assessment of mechanical performance of wooden members exposed to fire heating. Decreases of Young's Modulus caused by increasing of temperature and moisture content, and thermal softening at high moisture content and high temperature can be calculated with the proposed equation. Displacement of a beam and buckling time in a column during fire heating become able to be estimated with Young's Modulus decreased by both of temperature and moisture content.

Mechanical properties of wooden members exposed to fire heating had been estimated with only decreasing of crosssectional area by charring and increasing of temperature in remained cross sectional area in mainly previous study. However, not only temperature but also moisture content is important parameter because increasing of moisture content caused by vaporization, transfer, and re-condensation of water in remained cross sectional area required to bear load during fire and temperature dependence of mechanical properties increase significantly at high moisture content due to thermal softening of lignin and hemicellulose.

In this study, an equation calculating mechanical properties with temperature and moisture content is developed by regression analysis. Bending tests to determine a form of the equation for regression analysis was conducted before regression analysis. Only Young's Modulus which can be measured before/after heating with non-destructive was investigated. Young's Modulus remaining ratio $\mathrm{R}_{\mathrm{E}}$ was defined as a ratio of Young's Modulus before/after heating.

First, Young' s Modulus between temperature $45 \sim 95{ }^{\circ} \mathrm{C}$ is measured though heating at $5{ }^{\circ} \mathrm{C}$ intervals in bending tests. Decreases of Young's Modulus with temperature increasing is more significant at high moisture content state than bonedry state, and can be represented as by-linear line.

Secondly, regression analysis is conducted with results of previous bending tests (Ref.2),3,6),11) for temperature between $20^{\circ} \mathrm{C}$ and $250^{\circ} \mathrm{C}$, moisture content between $0 \%$ and $180.5 \%$. Constants in proposed equation is determined for each 5 tree species; Cryptomeria japonica, Chamaecyparis obtuse, Larix leptolepis, Pseudotsuga menziesii and Zelkova serrata. Decreases of Young's Modulus is defined to be caused by following 3 factors;

(1) Decreases of Young's Modulus are in proportional to temperature with temperature increasing at bone-dry state, and become larger above temperature thermal decomposition begin to affect.

(2) Changes of moisture content only under 30\% affect Young's Modulus at room temperature.

(3) Decreases of Young's Modulus become larger proportionally to temperature and moisture content above temperature thermal softening begin to affect. Limit of decreasing by thermal softening is represented by-linear line resulted in bending tests in this study.

Finally, calculated results with proposed equation represent appropriately for results of bending tests. Differences of temperature dependence of Young's modulus between each tree species is small at bone-dry density, and large at high moisture content. Young's modulus remaining ratio at high moisture content decrease to 0.57 in Cryptomeria japonica, 0.35 in Zelkova serrata even under $100^{\circ} \mathrm{C}$.

In the future, distribution of temperature and moisture content within actual wooden member should be measured and enable to be calculated with a model for heat and water transfer. Moreover, influence of moisture content for bending rigidity should be clarified with proposed equation. The equation required to be applied for calculating bending strength or compression strength, and predict mechanical properties of other tree species. 